\title{
China's Terrestrial Ecosystem Carbon Balance During The 20th Century: An Analysis With A Process-Based Biogeochemistry Model
}

Yanyu Lu ( $\sim$ ahqxlyy@163.com )

Anhui Institute of Meteorological Sciences https://orcid.org/0000-0003-4497-9567

\section{Yao Huang}

Institute of Botany Chinese Academy of Sciences

Qianlai Zhuang

Purdue University

Wei Sun

anhui institute of meteorological sciences

Shutao Chen

Nanjing University of Information Science and Technology

Jun Lu

The University of Tulsa

Research

Keywords: China, Terrestrial Ecosystem Model, Carbon cycle, Climate change, Land use, Hu Huanyong line

Posted Date: February 25th, 2021

DOI: https://doi.org/10.21203/rs.3.rs-230437/v1

License: (c) (i) This work is licensed under a Creative Commons Attribution 4.0 International License. Read Full License 


\section{Abstract}

China's terrestrial ecosystems play a pronounced role in the global carbon cycle. Here we combine spatially-explicit information on vegetation, soil, topography, climate and land use change with a processbased biogeochemistry model to quantify the responses of terrestrial carbon cycle in China during the $20^{\text {th }}$ century. We find that that the regional soil thermal and moisture regimes have dramatically changed. Specifically, evapotranspiration increased due to rising temperature and soils were drying in the last two decades of the $20^{\text {th }}$ century. At a century scale, China's terrestrial ecosystems have acted as a carbon sink averaging at $0.09 \mathrm{Pg} \mathrm{C} \mathrm{yr}^{-1}$, with large inter-annual and decadal variabilities. The regional sink has been enhanced due to the rising temperature and $\mathrm{CO}_{2}$ concentration, with a slight increase trend in carbon sink strength along with the enhanced net primary production in the century. Meanwhile, the heterotrophic respiration increased in response to warming. The spatial and temporal variabilities of carbon balance in China are due to multiple controlling factors including temperature and precipitation and changing atmospheric $\mathrm{CO}_{2}$ concentrations. Land-use changes including reforestation and afforestation during the late $20^{\text {th }}$ century partially contributed to the increase in carbon sink at the national scale.

\section{Introduction}

Terrestrial ecosystems play an important role in the global carbon (C) cycle and have been found to act as net carbon sinks, offsetting $10-60 \%$ of the $\mathrm{CO}_{2}$ emitted through human activities over last decades (Ciais et al., 2014; Le Quéré et al., 2015). As a country with vast territory area and the world's largest population, China significantly contributes to the global carbon balance in terms of both carbon emission (Boden et al., 2009) and carbon uptake (Piao et al., 2009a). Since 2006, China has become the largest $\mathrm{CO}_{2}$ emitter, accounting for $27 \%$ of global emissions (Gregg et al., 2008). Whether China can effectively contribute to the mitigation of global warming depends on the magnitude of net $\mathrm{C}$ balance (Shao et al., 2016), highlighting the need to adequately quantify the carbon balance of terrestrial ecosystems $C$ cycle in China.

China's terrestrial ecosystems have been recognized as a substantial carbon sink in recent decades (Piao et al., 2009a; Tian et al., 2011a, b; Shao et al., 2016). However, there was a remarkable uncertainty on whether the terrestrial ecosystems in China are sinks or sources for atmospheric $\mathrm{CO}_{2}$ because they depend heavily on changing climate and land use as well as atmospheric $\mathrm{CO}_{2}$. Over the past century, the average air temperature in China has increased by 0.5 to $0.8^{\circ} \mathrm{C}$ (Ding et al., 2006), which is higher than the global average (IPCC, 2013). The timing and intensity of climate change in China tend to be above the global average level (Ding et al., 2007). The changes and feedbacks of East Asia summer monsoon systems (Ding and Chan, 2005) may even accelerate the climatic changes in this region. Furthermore, China has also been experiencing a dramatic land-use change that disturbs terrestrial carbon storage and fluxes and consequently has a particularly long-term impact on the carbon cycle at regional scales (Houghton and Hackler, 2003; Tian et al, 2011a). Chinese terrestrial ecosystems likely play a pronounced role in the global carbon dynamics in a changing climate (Fang et al., 2007; Piao et al., 2009a) and 
human society, which have drawn much attention from both the public and scientific community. To date, considerable efforts and progress have been made to improve our knowledge about China's carbon budget and its impact factors. However, due to the complex response and feedback of terrestrial carbon cycle to climate change and the anthropogenic disturbance, large uncertainties still exist in the carbon budget (Shao et al., 2016). The mechanisms and factors that govern the terrestrial carbon cycle are not yet fully accounted for in quantify the regional carbon budget (Piao et al., 2009b). In particular, the relationships between individual controlling factor and the spatial and temporal variabilities of carbon balance in China are still poorly quantified under the condition of concurrent changes and complex interactions of the major factors. Furthermore, to date, most studies have focused on the last several decades of the 20th century because the dramatic changes have been recognized to occur in the corresponding periods. Meanwhile, relatively little attention has been paid to the carbon budget of China's terrestrial ecosystems at a century scale. The role of ecosystems in carbon cycle during the early 20th century should not be ignored even if the relatively weak variabilities, because quantifying long-term terrestrial carbon dynamics will further help us to comprehensively understand the natural and anthropogenic contribution to global carbon cycle and climate change. Moreover, estimating the magnitudes of carbon fluxes at a century scale is critical for evaluating the ecosystem goods and services and cumulative contribution of regional ecosystems to carbon sequestration (Canadell et al., 2007; Ito, 2011; Li et al., 2016) and providing a scientific basis for international climate change negotiations (Heyward, 2011). The research is therefore of great importance to public as well as to policy makers.

Here we apply an extant process-based biogeochemistry model, the Terrestrial Ecosystem Model (TEM; Zhuang et al 2003, 2010) to quantify the carbon budget for China's terrestrial ecosystems during 19002000. Using the spatially explicit historical dataset, we examine how climate, atmospheric $\mathrm{CO}_{2}$ concentrations and land-use changes have collectively affected terrestrial $\mathrm{C}$ dynamics in China. The study also strives to identify the key controls to spatial and temporal patterns of $C$ dynamics in this region.

\section{Data And Methods}

\subsection{The Terrestrial Ecosystem Model}

The TEM is a process-based, global-scale ecosystem model that uses spatially referenced information on climate, elevation, soils, and vegetation to make monthly estimates of $\mathrm{C}$ fluxes and pool sizes of the terrestrial biosphere. In TEM, for each time step, net ecosystem productivity (NEP) is calculated as the difference between net primary productivity (NPP) and heterotrophic respiration (RH). NPP is calculated as the difference between gross primary production (GPP) and plant autotrophic respiration (RA). The structure, algorithm, parameterization, calibration and performance of TEM have been well documented (McGuire et al., 1992; Melillo et al., 1993; Zhuang et al., 2003, 2004, 2010). 
Although many of the parameters in the model are defined from published information (e.g., McGuire et al., 1992; Zhuang et al., 2003), some are determined by calibrating the model to fluxes and pool sizes of intensively studied field sites. For this application of TEM in China's terrestrial ecosystems, a set of parameters have been developed based on field observation data collected from different types of ecosystem at different regions (e.g. Zhuang et al., 2003; 2010). After calibration, the TEM was validated to be able to well reproduce the observed ecosystem $\mathrm{C}$ dynamics at site level in this region (Zhuang et al., 2009; 2010; Lu et al., 2009; Sui et al., 2013), which provides a sound basis for the application of TEM in this region.

\subsection{Spatially explicit data organization for simulation}

To run TEM in China for the 20th century, we organize the data of atmosphere, vegetation, ratio of croplands, soil texture, and elevation at $0.5^{\circ}$ latitude $\times 0.5^{\circ}$ longitude resolution from 1900 to 2000 . Specifically, the vegetation data over China are derived from the International Geosphere-Biosphere Program (IGBP) Data and Information System (DIS) DISCover Database (Loveland et al 2000) and reclassified into the TEM vegetation classification scheme (Melillo et al 1993). The soil texture data are based on the Food and Agriculture Organization/Civil Service Reform Committee (FAO/CSRC) digitization of the FAO-UNESCO soil map. For elevation, the $1 \mathrm{~km} \times 1 \mathrm{~km}$ elevation data derived from the Shuttle Radar Topography Mission (SRTM) (Farr et al., 2007) are adopted and re-sampled to match the resolution of other input data.

The driving climate data sets include the monthly air temperature, precipitation, and cloudiness. The historical climate data sets from 1900 to 2000 are based on the data from the CRU (Harris et al., 2014). The annual atmospheric $\mathrm{CO}_{2}$ concentrations data from 1900 to 2000 are based on observation and our previous studies (Zhuang et al., 2003, 2010). The spatially explicit dataset concerning dynamic land use change from 1900 to 2000 were derived from the HYDE database (Goldewijk et al., 2010).

\subsection{Regional simulation}

For each grid cell, we first run TEM to equilibrium for an undisturbed ecosystem using the long-term averaged monthly climate and $\mathrm{CO}_{2}$ concentrations from 1900 to 2000 . We then spin up the model for 150 years with the climate from 1900 to 1949 to account for the influence of inter-annual climate variability on the initial conditions of the undisturbed ecosystem. We finally run the model with transient input datasets from 1900 to 2000 to quantify carbon dynamics in China's terrestrial ecosystems.

\section{Results}

\subsection{Response of soil thermal and hydrological regimes to climate change}

During the 20th century, the climatic factors controlling terrestrial carbon cycle changes substantially and directly affected the soil thermal and moisture condition (Supplementary Fig. 1) across China. Driven by 
the increased air temperature, soil thermal dynamics simulated by TEM also exhibit an increasing trend during the 20th century. In particular, more significant increase trend occurs in the soil temperature at the top $20 \mathrm{~cm}$ depth with the rate of $0.23^{\circ} \mathrm{C}$ per decade for the period of 1970 to $2000\left(R^{2}=0.50 ; p<0.01 ; n=\right.$ 31). The mean precipitation over China shows a great inter-annual variability, while the change trend is not significant. At the national scale, annual averages of volumetric soil moisture are simulated to fluctuate between $46-49 \%$, mainly due to the variation of precipitation. A drying trend, however, occurs in soil moisture since the middle of the 1980s even though the decadal average of precipitation remains at almost the same level during the corresponding period. Sustained soil drying implies that the increase of evapotranspiration induced by rising temperature overwhelms the effect of precipitation on soil moisture and may reduce the water availability in China (Fu et al., 2008).

The changes in soil thermal and hydrological condition are not uniform across China. Figure 1 depicts the inter-annual variation in the simulated soil temperature and moisture at different longitudes and latitudes. For soil thermal dynamics, TEM simulation indicates that soil temperature at nearly all longitudes and latitudes has significantly increased during the 20th century, in particular for its last three decades (Fig. 1a, b). However, different change rates are found across China. Specifically, in comparison to the early last century, soil temperature during the last decade has increased by above $1.6^{\circ} \mathrm{C}$ in the north and east belts, which is remarkably higher than the magnitude of increase (below $1.0^{\circ} \mathrm{C}$ ) at the central and southern China. These spatiotemporal patterns of soil temperature changes correspond closely with the relatively large warming trend in air temperature in the northeast China (Ding et al., 2006). For soil hydrological dynamics, the changes in soil moisture have no significant trend but generally exhibit a decadal dry-wet cycle at different longitude and latitude strips (Fig. 1C, d). A larger inter-annual variability in soil moisture has been simulated in the east and high-latitude regions. It is noteworthy that there is persistent and extensive drought, as indicated by the negative anomalies of soil moisture, from 1922 to 1932 in the northern and eastern China, which is also recorded as one of the severest drought events in history (Tong et al., 2013). The consistency of the simulated extreme drought event with the actual historical record suggests that TEM is able to estimate soil moisture conditions in China.

\subsection{Terrestrial ecosystem carbon dynamics during the 20th century}

Our simulations indicate that China's terrestrial ecosystem acted as a $\mathrm{C}$ sink of $0.09 \mathrm{Pg} \mathrm{C} \mathrm{yr}^{-1}$ during the 20th century (Fig. 2a). This sink is the difference between NPP of $3.58 \mathrm{Pg} \mathrm{C} \mathrm{yr}^{-1}$ (Fig. 2b) and heterotrophic respiration (RH) of $3.49 \mathrm{Pg} \mathrm{C} \mathrm{yr}^{-1}$ (Fig. 2c). The $\mathrm{C}$ dynamics in China however exhibit a significant inter-annual variability. The terrestrial ecosystem has been estimated as a $\mathrm{C}$ source in 43 years during 1900-2000. Comparing with $\mathrm{RH}$, the changes in NPP fluctuate more intensively and dominate the sink-source oscillation in NEP.

Due to rising temperature, longer growing season, and the fertilization effects of increase atmospheric $\mathrm{CO}_{2}$ concentrations, the NPP over China increases at the rate of $38 \mathrm{Tg} \mathrm{C}$ per decade during the last 
century (Fig. 2b). A significant rising trend in the changes of $\mathrm{RH}$ is also found but at a relatively low rate (23 Tg C per decade). Consequently, as the difference of NPP and RH, the total NEP slightly increased from $0.08 \mathrm{Pg} \mathrm{C} \mathrm{yr}^{-1}$ in the 1900 s to $0.19 \mathrm{Pg} \mathrm{C} \mathrm{yr}^{-1}$ in the $1990 \mathrm{~s}$. However, it should be noted that since the 1970s the change rate of $\mathrm{RH}$ apparently accelerates in comparison to the changes in NPP. The aggravating carbon loss by $\mathrm{RH}$ partially offsets the increase in plant $\mathrm{C}$ uptake, even induces a slight decrease in $\mathrm{C}$ sink over China in the end of the 20th century. This suggests that the effects of rising temperature or the atmospheric $\mathrm{CO}_{2}$ concentrations on plant $\mathrm{C}$ uptake can't keep up with ecosystem C loss in this region under the condition of intensive climate change (Cramer et al., 2001; Lu et al., 2009).

Comparing with the $\mathrm{C}$ fluxes, the $\mathrm{C}$ pool sizes in China are relatively stable, and the relative change proportions are less than $15 \%$ through the 20th century (Fig. 2 d). TEM estimates that soil C pool size average at $56.56 \mathrm{Pg} \mathrm{C}$ over the last century and $56.11 \mathrm{Pg} \mathrm{C}$ in the $1990 \mathrm{~s}$. A decrease trend presents in the variation of soil $\mathrm{C}$ pool sizes in the late 20th century, as a result of the increase in $\mathrm{RH}$ during the corresponding period.

\subsection{Spatiotemporal patterns of terrestrial ecosystem carbon cycle}

There is a great spatial variability in carbon dynamics in China's terrestrial ecosystems, and the spatial pattern has also changed greatly during the 20th century (Fig. 3a d). NPP is simulated to vary from less than $50 \mathrm{~g} \mathrm{C} \mathrm{m}^{-2} \mathrm{yr}^{-1}$ to over $1200 \mathrm{~g} \mathrm{C} \mathrm{m}^{-2} \mathrm{yr}^{-1}$ across China. The south and east regions have higher NPP and the largest value is estimated in the tropical regions around the Tropic of Cancer, while the Northwest China and Tibet Plateau are dominated by the lowest plant productivity. Interestingly, the dividing line of $400 \mathrm{~g} \mathrm{C} \mathrm{m}^{-2} \mathrm{yr}^{-1}$ of NPP almost coincide with the Hu Huanyong line, a geo-demographic demarcation line which was proposed to illustrate the enormous difference in population density between the two sides of the line (Chen et al., 2016). Further, the dividing line of NPP is simulated to have not fundamentally changed during the 20th century, and the Hu Huanyong line also remains in place (Chen et al., 2016). The spatial congruence between net primary productivity and human population is also found in other regions (Luck, 2007). According to the phases of human development that influence population distribution in relation to NPP (Huston, 2005), the strong link between population and productivity firstly manifests the reliance of humans on local agricultural production, and the people then still prefer to settle in regions of relatively high NPP due to population agglomeration effect even though the local environmental constraints have been weakened by industrialization and urbanization.

During the 20th century, a substantial interdecadal variation has been found in the spatial pattern of NPP. The increase in NPP is simulated to occur in the east China, while the west regions are dominated by declining NPP, especially for the northwest. The spatial distribution of NEP indicates that most of China's terrestrial ecosystems act as a $\mathrm{C}$ sink (Fig. $3 \mathrm{e} \sim \mathrm{h}$ ). Specifically, the largest $\mathrm{C}$ sink with NEP over $100 \mathrm{~g} \mathrm{C}$ $\mathrm{m}^{-2} \mathrm{yr}^{-1}$ is located in the forest ecosystems of the southern China and the croplands in eastern China, while net $\mathrm{C}$ loss has been found in some arid regions in the northwest. Comparing with NPP, the interdecadal change in spatial pattern of NEP exhibits a relatively large variability. The role of terrestrial 
ecosystems acting as a $\mathrm{C}$ sink or a source can be found to shift frequently in most areas during the 20th century. Generally, the areas characterized by $\mathrm{C}$ source are simulated to extend in the west and north of the Hu Huanyong line, since the water scarcity in these regions constrains the increase in vegetation productivity and C uptake (Gao et al., 2014; Wiesmeier et al., 2015). Meanwhile, the eastern and southern regions increase their area and intensity of $C$ sink, particularly in the late 20th century.

\subsection{Contribution of different ecosystems}

Over the 20th century, forest ecosystems dominate the $\mathrm{C}$ sink in China and are responsible for about $65 \%$ of the total sink (Fig. 4a). Croplands contribute the second largest C sink of $22.6 \mathrm{Tg} \mathrm{C} \mathrm{m}^{-2} \mathrm{yr}^{-1}$. Grasslands and shrublands account for $7 \%$ and $3 \%$ of the total NEP, respectively. The rest of sink, less than $0.1 \%$, is contributed by the wetlands. On a per unit area basis, forest ecosystems also have the largest $\mathrm{C}$ sink strengths, averaged at $25 \mathrm{~g} \mathrm{C} \mathrm{m}^{-2} \mathrm{yr}^{-1}$ during the last century (Fig. 4b). Although croplands are the second largest sink strengths, the mean NEP of croplands amount to less than half of the forest. Wetlands are characterized by higher $\mathrm{C}$ sink strengths than grasslands and shrublands, but their small area substantially limits their gross contribution.

Driven by climatic and land use changes, different interdecadal change patterns are found for different ecosystems. Specifically, fluctuations in decadal average NEP of forest ecosystems are simulated to dominate in the early 20th century, and then a significant increase trend is found in the second half of the last century. The total NEP of forests has a relatively large increase trend, mainly due to the large-scale reforestation and afforestation since the 1970s. The change of NEP in croplands almost synchronize with forest except the remarkable decrease in the 1960s and 1990s resulting from the high sensitivity of agriculture production to climate change and the emergence of extensively extreme events in cropland areas during the corresponding periods (Huang et al., 2007; Yu et al., 2014; Zhang et al., 2014). Land-use changes also affect the contribution of croplands, and the decrease in cropland area in the late 20th century diminished the increase trend of its NEP in comparison to the $C$ uptake on per area basis. The variation of NEP in grasslands and shrublands is basically in line with that of forest ecosystems, except the role of shrublands acting as a $\mathrm{C}$ source during the middle of the 20th century. The flux of wetlands has the largest inter-decadal variability among these ecosystems and does not show a significant change trend. On decadal average, most ecosystems act as a $\mathrm{C}$ sink during the 20th century except for the $1920 \mathrm{~s}$. Net $\mathrm{C}$ loss is simulated to occur in all ecosystems in the 1920 s, as a result of the persistent and extensive drought event as highlighted in Sect. 3.1.

\section{Discussion}

\subsection{Impact of major driving factors on carbon cycle}

We further conducted Spearman rank correlation analysis to identify the impact of main controls on the spatial and temporal variability in China's terrestrial $\mathrm{C}$ cycle. To exclude the interaction between different factors, the partial correlation $(K i m, 2015)$ has been adopted and suggests that the spatial pattern of $\mathrm{C}$ 
flux has been significantly influenced by various factors associated with climate, soil, topography and human activity (Supplementary Table 1). Among these factors, precipitation is the most important control to $C$ fluxes. The spatial patterns of NPP and NEP (Fig. 3) can be mainly explained by the distribution of precipitation. The high correlation between precipitation and $\mathrm{C}$ dynamics is consistent with the observations in the field and satellite products (Bai et al., 2004; Yu et al., 2012; Lin et al., 2014), suggesting that the water availability is highly limiting the vegetation growth and soil microbe activity in China's terrestrial ecosystems. Air temperature also reasonably influences the spatial variation of NPP and $\mathrm{RH}$, while NEP has a much weaker correlation with temperature (Supplementary Table 1). This may be attributed to the parallel positive response of NPP and RH to temperature (Piao et al., 2009b). In addition to thermal and water conditions, radiation is another important factor to affect terrestrial $\mathrm{C}$ dynamics by limiting photosynthesis (Nemani et al., 2003). Cloudiness exerts a significant control over the spatial variability in $\mathrm{C}$ fluxes by affecting light availability for plant growth in China (Table 1). Soil properties also play an important role in terrestrial $\mathrm{C}$ cycle. As an example, soil texture can influence the soil thermal and moisture regimes (Lu et al., 2006; Saxton and Rawis, 2006), thereby impacting $C$ storage and fluxes (Cai et al., 2016). The negative response of $C$ fluxes to the fraction of clay implies that loose soil texture may favor the vegetation $\mathrm{C}$ uptake and soil microbial activities in China. According to the partial correlation, the topography is another factor controlling the spatial pattern of $C$ fluxes. The impact of elevation on ecological community and climate may account for the response of $\mathrm{C}$ fluxes to altitude changes. Together with environmental factors, human activity can also considerably influence the terrestrial $\mathrm{C}$ cycle through altering the land ecosystems. The shift from natural ecosystems to croplands tends to reduce the local NPP but has no significant impact on $\mathrm{RH}$. Consequently, the variation in $\mathrm{C}$ sink strength per grid cell shows a negative response to the change of cropland area.

During the 20th century, climate change and human activity dramatically induces a temporal variability in terrestrial $\mathrm{C}$ cycle across China. The correlation between inter-annual variation in NEP and temperature is not as significant as expected (Fig. 5a). Specifically, negative responses of NEP to temperature are found in some boreal ecosystems in Northeast and Tibet as well as the arid areas in Northwest, where the warmer climate may stimulate more $\mathrm{C}$ release through $\mathrm{RH}$ than $\mathrm{C}$ uptake by plant growth (Vukićević et al., 2001; Piao et al., 2009b). Meanwhile, the ecosystems in southern China, especially for the southwest, are dominated by an increasing net $\mathrm{C}$ uptake along with temperature increase. Precipitation change is more strongly associated with the inter-annual variation in NEP than other factors and may be the primary driver for NEP variations (Fig. 5b). Further, NEP dynamics in the arid and semiarid northern regions show a more significant correlation with precipitation, since the plant growth is relatively more water-limited in these areas. Rising $\mathrm{CO}_{2}$ concentration favors the plant photosynthesis and $\mathrm{C}$ uptake through the fertilization effect. Positive responses of NEP to $\mathrm{CO}_{2}$ concentration are indeed found in most areas (Fig. 5c), but only a few of regions in Tibet, Southwest and Northeast China have significant correlations with a $95 \%$ confidence, suggesting other driving factors together with $\mathrm{CO}_{2}$ concentration controlling carbon dynamics during the last century. Similar to the pattern of land-use changes affecting the spatial variation of $\mathrm{C}$ fluxes, temporal changes in NEP exhibit a negative correlation with the changes in cropland 
area in East, Central, Southwest and Northeast China (Fig. 5d). The decrease of cropland area in these regions may partially contribute to the increase in local $\mathrm{C}$ uptake strength in the late 20th century.

\subsection{Comparison with other studies}

Carbon budgets of China's terrestrial ecosystems have been quantified at different time scales by using various methods in previous studies. A comparison of our results to other studies was conducted (Supplementary Table 2). At the national scale, our estimates of terrestrial $\mathrm{C}$ uptake agreed well with other estimates. For example, Piao et al. (2009) estimated that China's terrestrial ecosystems sequestered carbon at a rate of $186 \sim 261 \mathrm{Tg} \mathrm{C} \mathrm{yr}^{-1}$ from 1980 to 2002. Our simulated carbon sink of $196 \mathrm{Tg} \mathrm{C} \mathrm{yr}^{-1}$ is within this range. During the period of 1961-2000, TEM estimates a slightly lower C sink strength than the estimate reported by Tian et al. (2011a), mainly owing to not including the increase in $\mathrm{N}$ fertilizer application in our simulation and thereby underestimating $\mathrm{CO}_{2}$ sequestration in croplands. The average of NPP simulated by TEM at the century scale is $3.588 \mathrm{Pg} \mathrm{C} \mathrm{yr}^{-1}$ over China, which is close to a recent literature-based result (Shao et al., 2016). For the last two decades of the 20th century, NPP is estimated to vary from 2.94 to $3.96 \mathrm{Pg} \mathrm{C} \mathrm{yr}^{-1}$ by different studies (Piao et al., 2009a; Shao et al., 2016), and our result is consistent with these estimates. TEM estimate of $\mathrm{RH}$ is slightly higher than other estimates. TEM simulated soil organic carbon storage is considerably lower than $80 \mathrm{Pg} C$ that is commonly estimated in China's terrestrial ecosystems. The underestimate of soil carbon might be partially due to parameterization with limited observational data, which has also been shown in the previous site-level verification (Zhuang et al., 2010).

For the contribution of different ecosystems, our modeled results are fundamentally in line with the existing estimates. Specifically, during 1981-2000, the croplands in China are simulated in our study to sequester $\mathrm{CO}_{2}$ at a rate of $31 \mathrm{Tg} \mathrm{C} \mathrm{yr}^{-1}$, which is comparable to $39 \mathrm{Tg} \mathrm{C} \mathrm{yr}^{-1}$ reported by Huang and Sun (2006). TEM-simulated $\mathrm{C}$ sink of $13 \mathrm{Tg} \mathrm{C} \mathrm{yr}^{-1}$ for grassland is within the range of other estimates (Tian et al., 2011a). On a per unit area basis, our simulated NEP averages at $47 \mathrm{~g} \mathrm{C} \mathrm{m}^{-2} \mathrm{yr}^{-1}$ for China's forest ecosystems, which is slightly lower yet comparable to the result based on inventory method (Piao et al., 2009a).

For the variability of carbon dynamics, most studies have documented that NPP in China's terrestrial ecosystems has significantly increased over the late 20th century. Our simulation also shows a similar trend and magnitude of change in NPP. However, divergent change trends in NEP are estimated among different studies. Similar to some previous process-based model studies (e.g., Tian et al, 2011a), TEMsimulated rate of carbon accumulation in China's terrestrial ecosystems firstly accelerates and then slows down or even slightly decreases at the end of the last century. The discrepancy for the variation in $\mathrm{C}$ sink strength is mainly due to the difference in the estimate of soil carbon dynamics and storages, which will consequently incur a large uncertainty in the current regional carbon budget and future projection for terrestrial ecosystems. This suggests that the research priority should be directed to investigating the key controls on and processes of soil carbon dynamics and pool sizes as well as more detailed soil thermal 
and hydrological dynamics under a changing climate. In addition, the interaction among human activities, climate change, and ecosystems is with an even larger uncertainty. Some important factors concerning human activities such as the land management, fertilizer application, were not addressed in our simulations, which may introduce biases in our current estimates. To improve our analysis of regional carbon dynamics, further efforts should be made to quantify how human appropriate and alter the land ecosystems and its impacts on carbon cycle in China.

\section{Conclusion}

This study represents a new effort to explicitly examine the regional $C$ dynamics in response to climate change and human activity in China during the 20th century. We find that China's terrestrial ecosystems acted as a carbon sink of $0.09 \mathrm{Pg} \mathrm{C} \mathrm{yr}^{-1}$ in the last century with a large inter-annual and spatial variability. Our analysis further suggests that the historical changes in regional carbon cycle show complex responses to changes in climate, $\mathrm{CO}_{2}$ concentration, and land use. Driven by these factors, the regional $\mathrm{C}$ cycle has been accelerated, leading to an increase for both vegetation productivity and soil decomposition. Among these driving forces, the precipitation has been the most important control to the spatial and temporal variability of carbon fluxes from China's terrestrial ecosystems. Ecosystems' $\mathrm{C}$ sink or source is found to be highly sensitive to the hydrological conditions. The extensive droughts have caused the net carbon losses from almost all types of ecosystems during the 1920s. Among the major ecosystem types, forest contributes most to the $\mathrm{C}$ sink strength in China. Land-use changes including reforestation, afforestation and the shrink of cropland have prompted the net carbon uptake at the national scale. While a slight increase in carbon sink strength benefits from the enhanced vegetation carbon uptake during the 20th century, our simulations also show that the increase trend will diminish or even change to a decrease trend under a warming climate.

\section{Declarations}

\section{Acknowledgments}

This study is supported by National Key R\&D Program of China (2017YFC0503905), the Climate Change Special Fund (CCSF201734, CCSF201809), the Foundation for Young Talents of China Meolorolgical Administration, and the NSF project IIS-102795.

\section{Ethics approval and consent to participate}

Not applicable.

\section{Consent for publication}

Not applicable.

\section{Availability of data and materials}


The datasets during and/or analysed during the current study available from the corresponding author on reasonable request.

\section{Competing interests}

The authors declare that they have no competing interests.

\section{Funding}

This study is supported by National Key R\&D Program of China (2017YFC0503905), the Climate Change Special Fund (CCSF201734, CCSF201809), the Foundation for Young Talents of China Meolorolgical Administration, and the NSF project IIS-102795.

\section{Authors' contributions}

Yanyu Lu conceived the study and performed the analysis. All authors developed the methodology, discussed the results, and contributed to the preparation of the manuscript.

\section{References}

1. Bai Y, Han X, Wu J, Chen Z, Li L. Ecosystem stability and compensatory effects in the Inner Mongolia grassland. Nature. 2004;431:181-4. doi:10.1038/nature02850.

2. Bondeau A, Smith PC, Zaehle S, Schaphoff S, Lucht W, Cramer W, Gerten D, Lotze-Campen H, Müller C, Reichstein M, Smith B. Modelling the role of agriculture for the 20th century global terrestrial carbon balance. Glob Change Biol. 2007;13:679-706. doi:10.1111/j.1365-2486.2006.01305.x.

3. Botzen WJW, Gowdy JM, Bergh JCJMVD. Cumulative $\mathrm{CO}_{2}$ emissions: shifting international responsibilities for climate debt. Clim Policy. 2008;8:569-76. doi:10.3763/cpol.2008.0539.

4. Canadell JG, Quéré CL, Raupach MR, Field CB, Buitenhuis ET, Ciais P, Conway TJ, Gillett NP, Houghton RA, Marland G. Contributions to accelerating atmospheric $\mathrm{CO} 2$ growth from economic activity, carbon intensity, and efficiency of natural sinks. PNAS. 2007;104:18866-70. doi:10.1073/pnas.0702737104.

5. Chen M, Gong Y, Li Y, Lu D, Zhang H. Population distribution and urbanization on both sides of the Hu Huanyong Line: Answering the Premier's question. J Geogr Sci. 2016;26:1593-610. doi:10.1007/s11442-016-1346-4.

6. Chen S, Huang Y, Zou J, Shi Y, Lu Y, Zhang W, Hu Z. Interannual variability in soil respiration from terrestrial ecosystems in China and its response to climate change. Sci China Earth Sci. 2012;55:2091-8. doi:10.1007/s11430-012-4464-6.

7. Ciais P, Sabine C, Bala G, et al., 2014. Carbon and other biogeochemical cycles. In Climate change 2013: the physical science basis. Contribution of Working Group I to the Fifth Assessment Report of the Intergovernmental Panel on Climate Change. Cambridge University Press, 465-570. 
8. Cramer W, Bondeau A, Woodward FI, Prentice IC, Betts RA, Brovkin V, Cox PM, Fisher V, Foley JA, Friend AD, Kucharik C, Lomas MR, Ramankutty N, Sitch S, Smith B, White A, Young-Molling C. Global response of terrestrial ecosystem structure and function to $\mathrm{CO}_{2}$ and climate change: results from six dynamic global vegetation models. Glob Change Biol. 2001;7:357-73. doi:10.1046/j.13652486.2001.00383.x.

9. Ding Y, Ren G, Shi G, et al. National Assessment Report of Climate Change (I): Climate change in China and its future trend[J]. Advances in Climate Change Research. 2006;1:1-5.

10. Ding Y, Chan J. The East Asian summer monsoon: an overview. Meteorol Atmos Phys. 2005;89:11742. doi:10.1007/s00703-005-0125-z.

11. Ding Y, Ren G, Zhao Z, Xu Y, Luo Y, Li Q, Zhang J. Detection, causes and projection of climate change over China: An overview of recent progress. Adv Atmos Sci. 2007;24:954-71. doi:10.1007/s00376007-0954-4.

12. Fang J, Guo Z, Piao S, Chen A. Terrestrial vegetation carbon sinks in China, 1981-2000. Sci China Ser D. 2007;50:1341-50. doi:10.1007/s11430-007-0049-1.

13. Farr TG, Rosen PA, Caro E, et al., 2007. The Shuttle Radar Topography Mission. Rev. Geophys. 45, RG2004. doi:10.1029/2005RG000183.

14. Feng X, Liu G, Chen JM, Chen M, Liu J, Ju WM, Sun R, Zhou W. Net primary productivity of China's terrestrial ecosystems from a process model driven by remote sensing. Journal of Environmental Management Carbon Sequestration In China's Forest Ecosystems. 2007;85:563-73. doi:10.1016/j.jenvman.2006.09.021.

15. Fu C, Jiang Z, Guan Z, He J, Xu Z. 2008. Impacts of Climate Change on Water Resources and Agriculture in China, Regional Climate Studies of China, Regional Climate Studies. Springer, Berlin, pp. 447-64. doi:10.1007/978-3-540-79242-0_11.

16. Gao Y, Zhu X, Yu G, He N, Wang Q, Tian J. 2014. Water use efficiency threshold for terrestrial ecosystem carbon sequestration in China under afforestation. Agric For Meteorol. 195-6, 32-37. doi:10.1016/j.agrformet.2014.04.010.

17. Gregg JS, Andres RJ, Marland G. China: Emissions pattern of the world leader in $\mathrm{CO} 2$ emissions from fossil fuel consumption and cement production. Geophys Res Lett. 2008;35:L08806. doi:10.1029/2007GL032887.

18. Harris I, Jones Pd, Osborn Tj, Lister Dh. Updated high-resolution grids of monthly climatic observations - the CRU TS3.10 Dataset. Int J Climatol. 2014;34:623-42. doi:10.1002/joc.3711.

19. Heyward M. Equity and international climate change negotiations: a matter of perspective. Clim Policy. 2007;7:518-34. doi:10.1080/14693062.2007.9685674.

20. Houghton RA, Hackler JL. Sources and sinks of carbon from land-use change in China. Global Biogeochem Cycles. 2003;17:1034. doi:10.1029/2002GB001970.

21. Huang $Y$, Sun $W$. Changes in topsoil organic carbon of croplands in mainland China over the last two decades. CHINESE SCI BULL. 2006;51:1785-803. doi:10.1007/s11434-006-2056-6. 
22. Huang Y, Zhang W, Sun W, Zheng X. Net Primary Production of Chinese Croplands from 1950 to 1999. Ecol Appl. 2007;17:692-701. doi:10.1890/05-1792.

23. Huston MA. The Three Phases of Land-Use Change: Implications for Biodiversity. Ecol Appl. 2005;15:1864-78. doi:10.1890/03-5281.

24. IPCC. 2013: climate change 2013: the physical science basis. Contribution of working group I to the fifth assessment report of the intergovernmental panel on climate change. 2013.

25. Ito A. A historical meta-analysis of global terrestrial net primary productivity: are estimates converging? Glob Change Biol. 2011;17:3161-75. doi:10.1111/j.1365-2486.2011.02450.x.

26. Kim S. ppcor: An R Package for a Fast Calculation to Semi-partial Correlation Coefficients. Commun Stat Appl Methods. 2015;22:665-74. doi:10.5351/CSAM.2015.22.6.665.

27. Klein Goldewijk K, Beusen A, van Drecht G, de Vos M. The HYDE 3.1 spatially explicit database of human-induced global land-use change over the past 12,000 years. Glob Ecol Biogeogr. 2011;20:7386. doi:10.1111/j.1466-8238.2010.00587.x.

28. Le Quéré C, Moriarty R, Andrew RM, et al. Global Carbon Budget 2015. Earth System Science Data. 2015;7:349-96. doi:10.5194/essd-7-349-2015.

29. Li B, Gasser T, Ciais P, Piao S, et al. The contribution of China's emissions to global climate forcing. Nature. 2016;531:357-61. doi:10.1038/nature17165.

30. Lin X, Li J, Luo J, Wu X, Tian Y, Wang W. 2015. Precipitation Mediates the Response of Carbon Cycle to Rising Temperature in the Mid-to-High Latitudes of the Northern Hemisphere. PLoS One 10. doi:10.1371/journal.pone.0132663.

31. Loveland TR, Reed BC, Brown JF, Ohlen DO, Zhu Z, Yang L, Merchant JW. Development of a global land cover characteristics database and IGBP DISCover from $1 \mathrm{~km}$ AVHRR data. Int J Remote Sens. 2000;21:1303-30. doi:10.1080/014311600210191.

32. Lu S, Ren T, Gong Y, Horton R. An Improved Model for Predicting Soil Thermal Conductivity from Water Content at Room Temperature. Soil Sci Soc Am J. 2007;71:8-14. doi:10.2136/sssaj2006.0041.

33. Lu Y, Zhuang Q, Zhou G, Sirin A, Melillo J, Kicklighter D. Possible decline of the carbon sink in the Mongolian Plateau during the 21st century. Environ Res Lett. 2009;4:045023. doi:10.1088/17489326/4/4/045023.

34. Luck GW. The relationships between net primary productivity, human population density and species conservation. J Biogeogr. 2007;34:201-12. doi:10.1111/j.1365-2699.2006.01575.x.

35. McGuire AD, Melillo JM, Joyce LA, Kicklighter DW, Grace AL, Moore B, Vorosmarty CJ. Interactions between carbon and nitrogen dynamics in estimating net primary productivity for potential vegetation in North America. Global Biogeochem Cycles. 1992;6:101-24. doi:10.1029/92GB00219.

36. Melillo JM, McGuire AD, Kicklighter DW, Moore B, Vorosmarty CJ, Schloss AL. Global climate change and terrestrial net primary production. Nature. 1993;363:234-40. doi:10.1038/363234a0. 
37. Nemani RR, Keeling CD, Hashimoto H, Jolly WM, Piper SC, Tucker CJ, Myneni RB, Running SW. Climate-Driven Increases in Global Terrestrial Net Primary Production from 1982 to 1999. Science. 2003;300:1560-3. doi:10.1126/science.1082750.

38. Piao S, Fang J, Ciais P, Peylin P, Huang Y, Sitch S, Wang T. The carbon balance of terrestrial ecosystems in China. Nature. 2009a;458:1009-13. doi:10.1038/nature07944.

39. Piao S, Ciais P, Friedlingstein P, de Noblet-Ducoudré N, Cadule P, Viovy N, Wang T. Spatiotemporal patterns of terrestrial carbon cycle during the 20th century. Global Biogeochem Cycles. 2009b;23:GB4026. doi:10.1029/2008GB003339.

40. Shao J, Zhou X, Luo Y, et al. Uncertainty analysis of terrestrial net primary productivity and net biome productivity in China during 1901-2005. J Geophys Res Biogeosci. 2016;121:2015JG003062. doi:10.1002/2015JG003062.

41. Sui X, Zhou G, Zhuang Q. Sensitivity of carbon budget to historical climate variability and atmospheric $\mathrm{CO} 2$ concentration in temperate grassland ecosystems in China. Clim Change. 2013;117:259-72. doi:10.1007/s10584-012-0533-2.

42. Tian H, Melillo J, Lu C, Kicklighter D, Liu M, Ren W, Xu X, Chen G, Zhang C, Pan S, Liu J, Running S. China's terrestrial carbon balance: Contributions from multiple global change factors. Global Biogeochem Cycles. 2011a;25:GB1007. doi:10.1029/2010GB003838.

43. Tian H, Xu X, Lu C, Liu M, Ren W, Chen G, Melillo J, Liu J. Net exchanges of CO2, CH4, and N2O between China's terrestrial ecosystems and the atmosphere and their contributions to global climate warming. J Geophys Res. 2011b;116:G02011. doi:10.1029/2010JG001393.

44. Tong A, Wang J, Li Y. The disaster and causes of serious drought in seven provinces of Northern China in 1920s. Journal of Arid Meteorology. 2013;31(4):750-5.

45. Vukićević T, Braswell BH, Schimel D. A diagnostic study of temperature controls on global terrestrial carbon exchange. Tellus B: Chemical Physical Meteorology. 2001;53:150-70. doi:10.3402/tellusb.v53i2.16570.

46. Wiesmeier M, Munro S, Barthold F, Steffens M, Schad P, Kögel-Knabner I. Carbon storage capacity of semi-arid grassland soils and sequestration potentials in northern China. Glob Change Biol. 2015;21:3836-45. doi:10.1111/gcb.12957.

47. Yu G, Zhu X, Fu Y, et al. Spatial patterns and climate drivers of carbon fluxes in terrestrial ecosystems of China. Glob Change Biol. 2013;19:798-810. doi:10.1111/gcb.12079.

48. Yu Y, Zhang W, Huang Y. Impact assessment of climate change, carbon dioxide fertilization and constant growing season on rice yields in China. Clim Change. 2014;124:763-75. doi:10.1007/s10584-014-1129-9.

49. Yuan Q, Wu S, Zhao D, Dai E, Chen L, Zhang L. Modeling net primary productivity of the terrestrial ecosystem in China from 1961 to 2005. J Geogr Sci. 2014;24:3-17. doi:10.1007/s11442-014-1069-3.

50. Zhang W, Yu Y, Li T, Sun W, Huang Y. Net Greenhouse Gas Balance in China's Croplands over the Last Three Decades and Its Mitigation Potential. Environ Sci Technol. 2014;48:2589-97. doi:10.1021/es404352h. 
51. Zhuang Q, McGUIRE AD, Melillo JM, Clein JS, Dargaville RJ, Kicklighter DW, Myneni RB, Dong J, Romanovsky VE, Harden J, Hobbie JE. Carbon cycling in extratropical terrestrial ecosystems of the Northern Hemisphere during the 20th century: a modeling analysis of the influences of soil thermal dynamics. Tellus B. 2003;55:751-76. doi:10.1034/j.1600-0889.2003.00060.x.

52. Zhuang Q, Melillo JM, Kicklighter DW, Prinn RG, McGuire AD, Steudler PA, Felzer BS, Hu S. Methane fluxes between terrestrial ecosystems and the atmosphere at northern high latitudes during the past century: A retrospective analysis with a process-based biogeochemistry model. Global Biogeochem Cycles. 2004;18:GB3010. doi:10.1029/2004GB002239.

53. Zhuang Q, Zhang T, Xiao J, Luo T. Quantification of net primary production of Chinese forest ecosystems with spatial statistical approaches. Mitig Adapt Strateg Glob Change. 2009;14:85-99. doi:10.1007/s11027-008-9152-7.

54. Zhuang Q, He J, Lu Y, Ji L, Xiao J, Luo T. Carbon dynamics of terrestrial ecosystems on the Tibetan Plateau during the 20th century: an analysis with a process-based biogeochemical model. Glob Ecol Biogeogr. 2010;19:649-62. doi:10.1111/j.1466-8238.2010.00559.x.

\section{Figures}
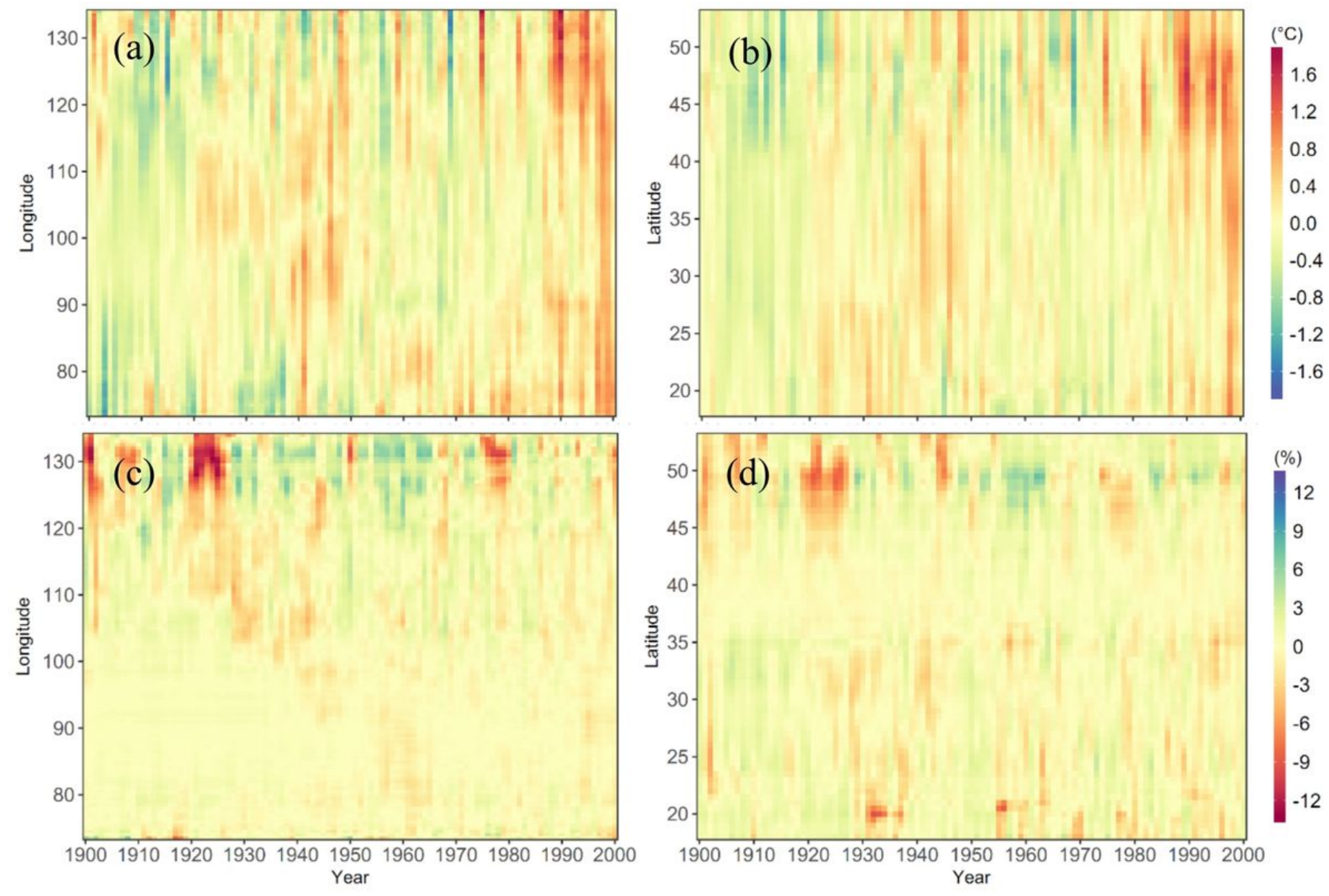

Figure 1 
Inter-annual variation in anomalies of annual soil temperature at top $20 \mathrm{~cm}$ soil depth $(\mathrm{a}, \mathrm{b})$ and moisture (c, d) at different longitudes (a, c) and latitudes (b, d) from 1900 to 2000 in China
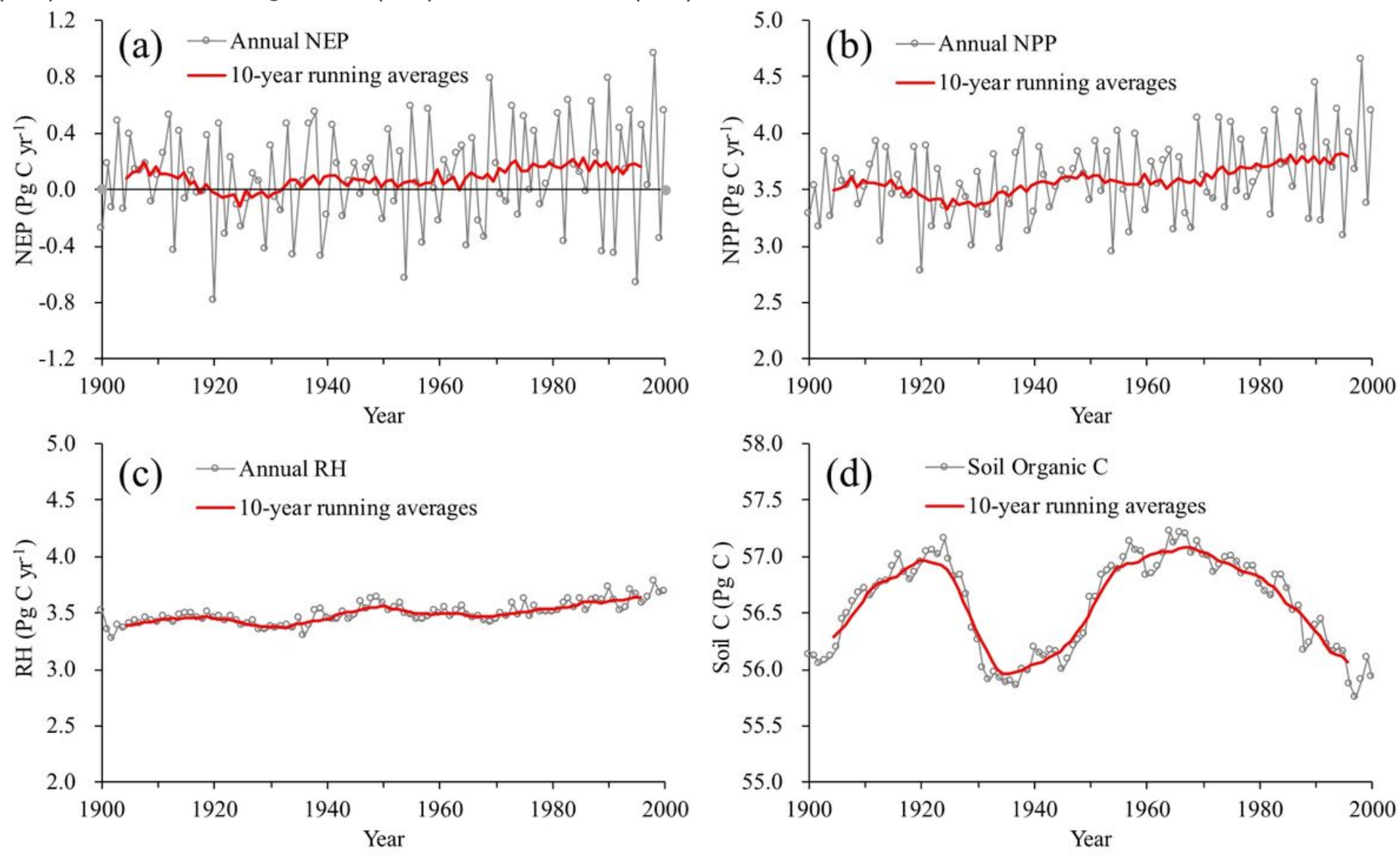

\section{Figure 2}

Inter-annual variability for (a) net ecosystem production (NEP), (b) net primary production (NPP), (c) heterotrophic respiration (RH) and (d) soil carbon pool from 1900 to 2000 in China. 

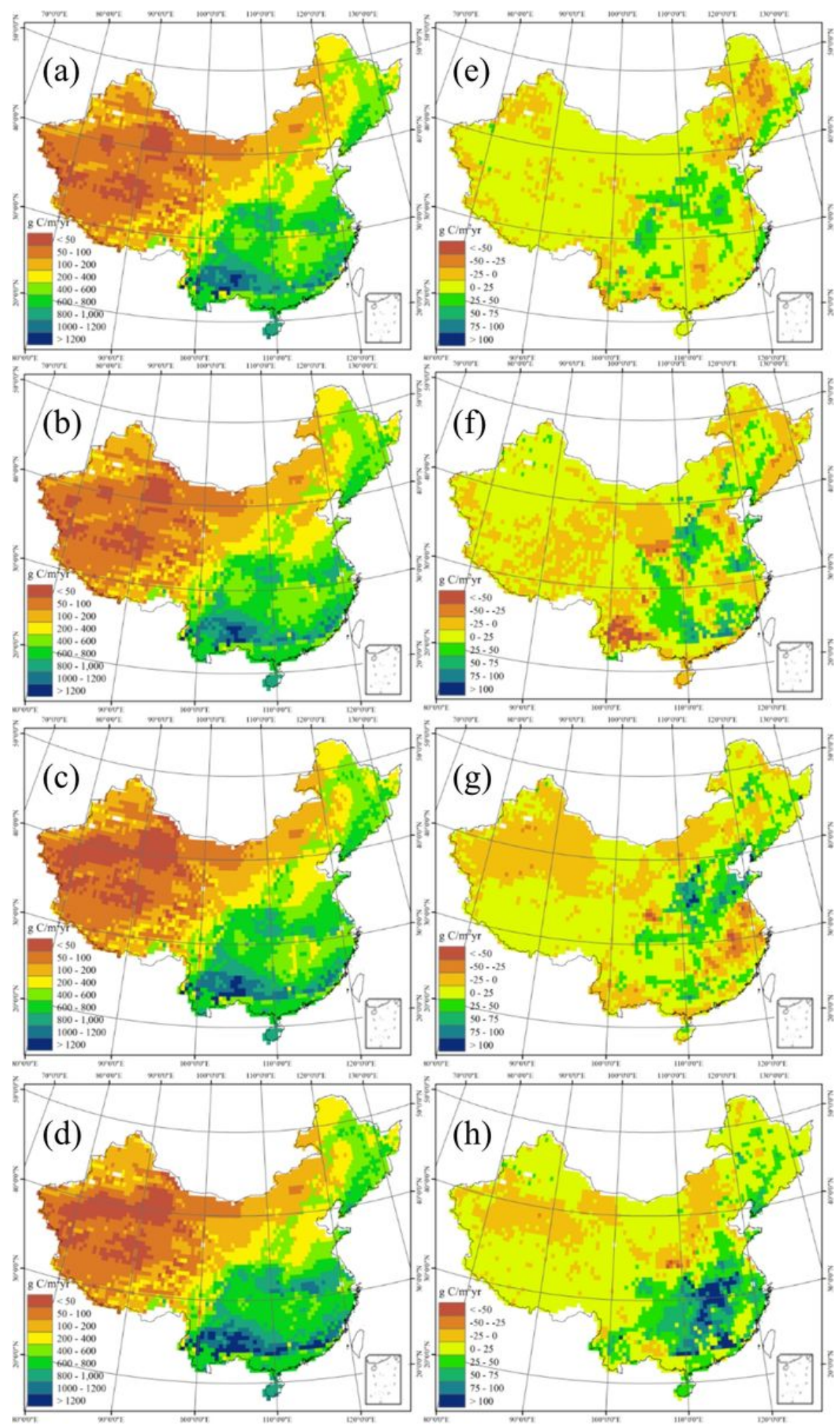

Figure 3

Spatial patterns of annual net primary production (NPP, a $\sim$ d) and net ecosystem production (NEP, e $\sim \mathrm{h}$ ) during the1900s (a, e), 1930s (b, f), 1960s (c, g), and 1990s (d, h) in China. Note: The designations employed and the presentation of the material on this map do not imply the expression of any opinion whatsoever on the part of Research Square concerning the legal status of any country, territory, city or 
area or of its authorities, or concerning the delimitation of its frontiers or boundaries. This map has been provided by the authors.

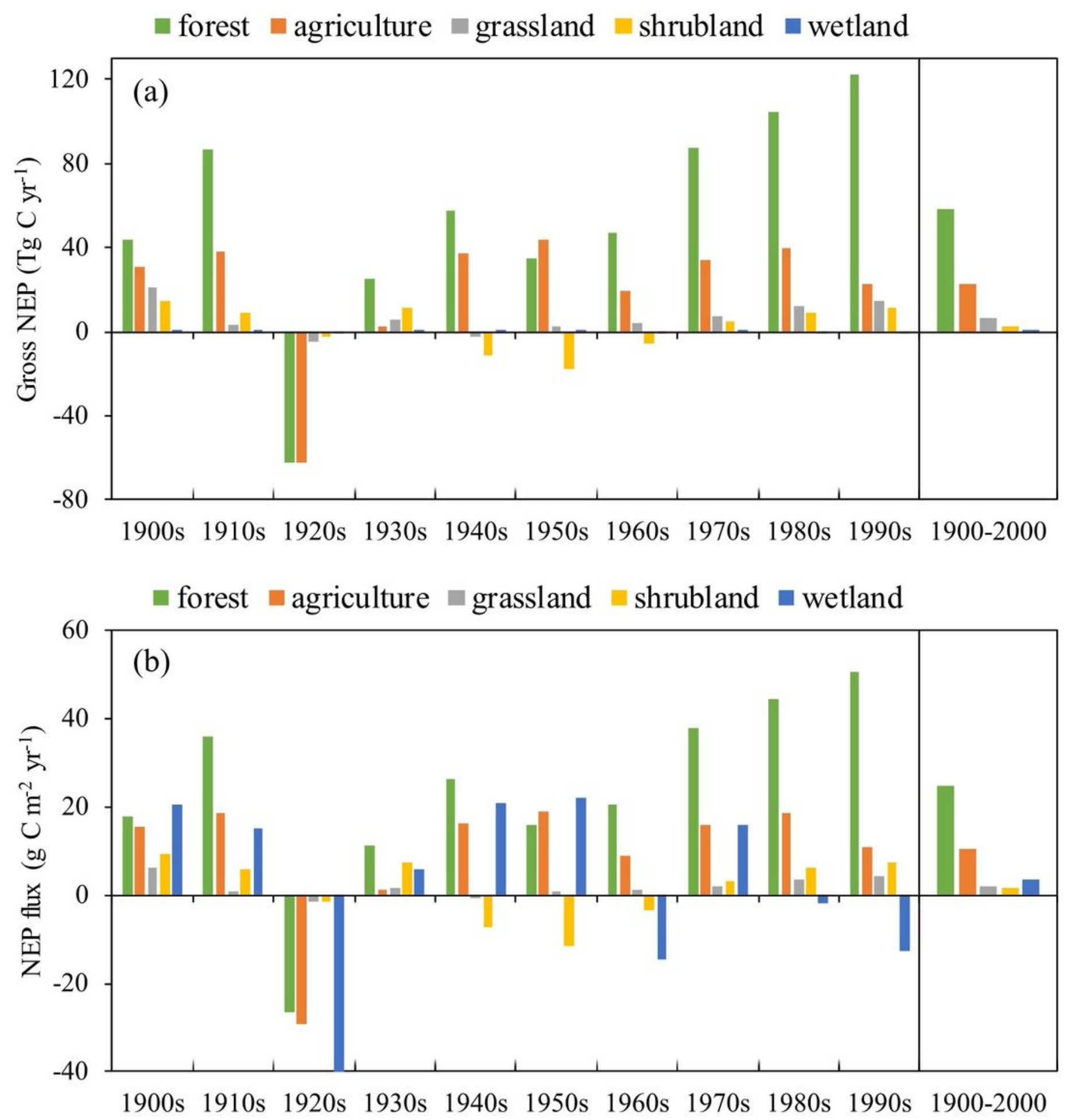

Figure 4

Net ecosystem production (NEP) of major ecosystem types in China during different decades. (a) gross NEP, (b) NEP on per area basis. 

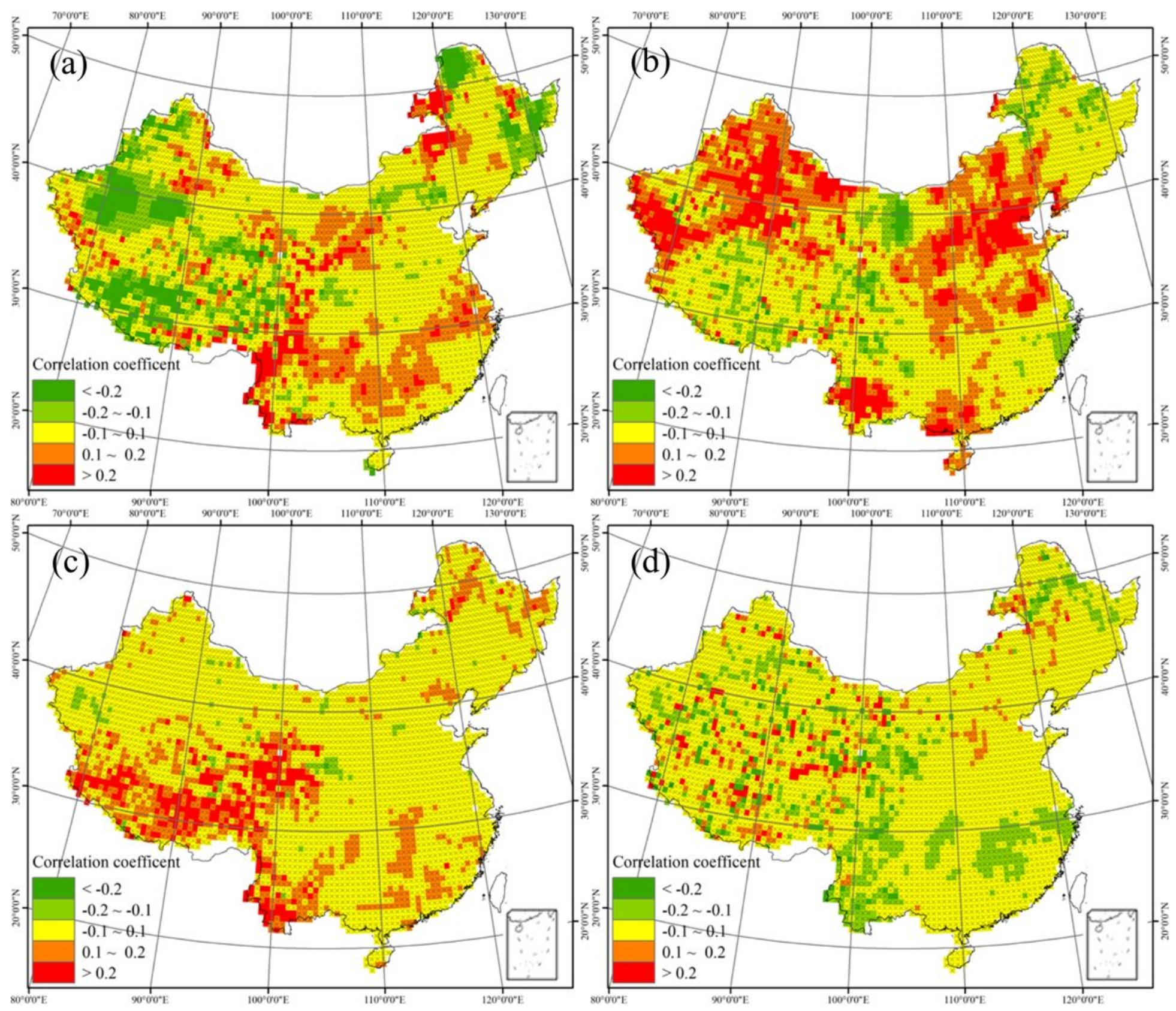

Figure 5

Spatial patterns of partial correlation coefficients between net ecosystem production (NEP) and (a) air temperature, (b) precipitation, (c) CO2 concentration, and (d) ratio of cropland area from 1900 to 2000 in China. Black cross marks that the correlation does not pass the significant test with a $95 \%$ confidence. Note: The designations employed and the presentation of the material on this map do not imply the expression of any opinion whatsoever on the part of Research Square concerning the legal status of any country, territory, city or area or of its authorities, or concerning the delimitation of its frontiers or boundaries. This map has been provided by the authors.

\section{Supplementary Files}


This is a list of supplementary files associated with this preprint. Click to download.

- Supplementarymaterial.docx 